\title{
Party politics at the water's edge: contestation of military operations in Europe ${ }^{t}$
}

\author{
WOLFGANG WAGNER ${ }^{1 *}$, ANNA HERRANZ-SURRALLÉS ${ }^{2}$, \\ JULIET KAARBO ${ }^{3}$ AND FALK OSTERMANN ${ }^{4}$ \\ ${ }^{1}$ Department of Political Science and Public Administration, Vrije Universiteit Amsterdam, Amsterdam, \\ The Netherlands \\ ${ }^{2}$ Department of Political Science, Faculty of Arts and Social Sciences, Maastricht University, Maastricht, \\ The Netherlands \\ ${ }^{3}$ School of Social and Political Science, University of Edinburgh, Edinburgh, UK \\ ${ }^{4}$ Institut für Politikwissenschaft, Justus-Liebig-Universität Gießen, Gießen, Germany
}

This paper contributes to current debates on the politicization of international politics by examining party-political contestation of peace and security missions. It is guided by two inter-related questions, (a) to what extent deployment decisions are contested amongst political parties and (b) what drives such contestation. We examine data from a new data set on parliamentary votes on deployment decisions in France, Germany, Spain, and the United Kingdom and from the Chapel Hill Expert Survey. Against conventional wisdom and in an effort to address the often-overlooked role of political parties, we find that military deployments have been systematically contested amongst political parties across Europe. Further, we find that contestation is driven by the left/right axis, as opposed to newer cleavages captured here by the so-called gal/tan axis. We also find evidence that patterns of contestation depend on parties' positions in government or opposition, a factor we relate to bureaucratic and international pressures on the parties in office, and to political opportunities for opposition parties.

Keywords: party politics; military missions; contestation; politicization; defence policy

\section{Introduction}

Scholars of international relations have highlighted the growing politicization of international politics (Zürn, 2014). Proponents of the politicization thesis have argued that, with furthering globalization, international institutions' policies and

${ }^{\dagger}$ Earlier versions of this paper were presented at the workshop Legislatures and foreign affairs: political parties, committees, and individual MPs at the University of Tampere, 14 April 2016, at the Research on International Security and Conflict seminar at the University of Amsterdam on 20 April 2016, at the convention of the Central and Eastern European International Studies Association in Ljubljana on 24 June 2016, at the Wissenschaftszentrum Berlin on 28 July 2016 and at the workshop (Re-)Politicizations of Security. Concepts and Practices at the European Workshops in International Studies at Cardiff University, 7-10 June 2017.

* E-mail: w.m.wagner@vu.nl 
procedures have 'become salient and controversial on the level of mass politics' (Ecker-Ehrhardt, 2014: 1275). Beyond assessing the extent of the domestic and transnational politicization of international norms and institutions, research has concentrated on identifying the drivers behind this contestation, in particular, the relevance of classical ideological cleavages related to economic redistribution compared to new cleavages emerging as a consequence of globalization. These cleavages have been variously characterized as integration vs. demarcation (Kriesi et al., 2008; Grande and Kriesi, 2015), communitarian vs. cosmopolitan (Zürn, 2014; Zürn and de Wilde, 2016), libertarian vs. traditionalist (Bornschier, 2010), or green/alternative/libertarian vs. traditional/authoritarian/nationalist (gal/tan) (Hooghe et al., 2002). This has been best documented in relation to European integration (de Wilde et al., 2016; Hutter et al., 2016; Hooghe and Marks, 2018) and areas of global governance such as trade, development, environment and public health (cf. Zürn and Ecker-Ehrhardt, 2013), but less so in the area of international security, in particular the use of armed forces in the context of international security operations.

However, as critically shown by episodes such as the Iraq war in 2003, decisions on military deployments can also become salient issues in domestic elections, polarize political elites and trigger both domestic and transnational social mobilization (cf. Danchev and Macmillan, 2005; Chan and Safran, 2006; Schuster and Maier, 2006; Miyagi, 2009; Kaarbo and Cantir, 2013). Since the Iraq war, parliamentary votes on troop deployments in Europe have also become more common, with a growing number of countries having strengthened the rights of parliaments in the authorization of military operations (Wagner et al., 2017). The questioning of existing international military engagements has also figured prominently in the electoral programmes of some ascendant populist parties in Europe (Balfour et al., 2016). These examples suggest that a neglect of party politics in matters of the use of force is unjustified.

Although research on international security has long challenged the perspective that 'politics stops at the water's edge' and has recognized the significance of domestic politics to security policy (cf. Rosenau, 1966; Levy, 1986; Hermann and Peacock, 1987; Auerswald, 1999; Gourevitch, 2002), little attention has been paid to ideological dimensions and to political parties specifically. ${ }^{1}$ Likewise, comparative politics' work on political parties rarely includes foreign and security policy as a relevant dimension of party politics (cf. Verbeek and Zaslove, 2015: 525-526). In this paper though, we bring together insights from research on politicization, foreign policy analysis, and comparative politics to examine the party-political contestation of peace and security missions at the core of international security politics. We challenge the conventional wisdom, still extant in both international relations and comparative politics disciplines, that security issues generate

\footnotetext{
${ }^{1}$ A notable exception is Rathbun (2004) and some more recent research cited later in this paper, though mostly focusing on single case studies.
} 
cross-party consensus and we directly examine the role of party ideologies and party politics.

Going beyond single case studies, this paper addresses two inter-related questions: (a) to what extent deployment decisions are systematically contested amongst political parties, that is whether supporters and opponents cluster predictably in the political space and (b) what motivates and drives such contestation. We explore two types of data on party positioning on military missions by European democracies. First, we utilize experts' estimates of political parties' positions on peace and security missions in 31 European countries from the Chapel Hill Expert Survey (CHES) to map parties and party families on both a standard left vs. right spectrum and the 'new politics' gal vs. tan dimension. Second, presenting the new Parliamentary Deployment Votes Database, we examine parliamentary votes on deployment decisions in France, Germany, Spain, and the United Kingdom. Whereas the CHES data come with the advantage of covering a large number of countries, the voting data provide us with further insights into the degree and nature of contestation between and within political parties.

The paper proceeds in five steps. The second section sets the theoretical parameters of the analysis by elaborating on why we might expect party-political differences over the use of military force - a question often overlooked by mainstream theories in international relations, comparative politics, and by research on the domestic politics of security policy. Third section presents the data and methods in more detail. Special attention is given to the introduction of our new data set on parliamentary deployment votes in France, Germany, Spain, and the United Kingdom. Fourth section shows the results of our empirical analyses. We first report to what extent deployment decisions are contested amongst political parties using both CHES data and an Agreement Index (AI), adapted from studies of the European Parliament, to compare the degree of contestation of military deployments with other policy areas. We then investigate the drivers of party contestation over security missions, looking both at the effect of ideological cleavages and of parties' position in government and opposition. Last section concludes by summarizing the findings and discussing the implications for current debates on the politicization of international politics.

\section{Party-political contestation of military missions}

Traditionally, neither students of international relations nor their colleagues in comparative politics expect a great deal of party-political contestation over foreign policy, particularly security policy. International Relations scholars historically treated states as unitary actors and tended to examine national interests and national identity rather than competing party-political visions over foreign policy. Neorealists, for example, expect states to rationally unify in response to the imperatives of anarchy. Constructivists, in turn, tend to focus on international norms and logics of appropriateness, operating at the systemic level, with norms 
internalized by the state as a whole. Even constructivists who look inside the state at identities, roles, and ontological security also tend to assume a unified state as the key actor (cf. Cantir and Kaarbo, 2016: 3-9). Liberalism either remains at the system level (neoliberalism) or places the focus on public opinion and democratic institutions (democratic peace). Even if parties do have underlying differences on matters of security, scholarship on international conflict has often assumed that these differences might be suppressed in the face of external threats (Simmel, 1955; Levine and Campbell, 1972; Huddy, 2013). International crises bring about, at least temporarily, a rally around the flag-effect (Waltz, 1967: 273; Oneal et al., 1996) that unites domestic political actors and makes criticism of the government look inappropriate. According to the Copenhagen School, when elites securitize issues that is, framing them as a matter of security, they take them beyond normal politics and out of bounds for party contestation (Buzan et al., 1998: 29). Taken together, the idea that politics stops at the water's edge suggests that dissent on deployment decisions is rather unlikely as such votes may transcend party politics and demonstrate national unity instead.

Although theories of international relations are increasingly incorporating domestic political factors (Kaarbo, 2015), and Foreign Policy Analysis has, for decades, focused on the domestic politics of international relations, there has been very little attention to parties as ideational and political agents in security policy. Within the study of comparative politics, in turn, scholars emphasize that the emergence of political parties is best understood as a response to domestic conflict (Lipset and Rokkan, 1967). Conflicts over foreign and security politics do not figure prominently in explanations of party systems, which have emphasized economic, cultural and religious cleavages (Boix, 2007: 513). The few studies that focus on the role of political parties in politicizing international governance have also concentrated on economic and cultural issues, most notably trade and migration (Ecker-Ehrhardt, 2014). When addressed, contestation on security issues is more often related to the phenomenon of transnational politicization, for example the emergence of anti-war (global) protest movements, rather than its role in the domestic political and electoral spheres (cf. Lichbach and de Vries, 2007). Overall, therefore, it is generally assumed that voters care more about party positions on other issues, particularly domestic policy and economic pocket-book issues, and thus have little motivation to distinguish themselves in security policy.

More recently, however, research on foreign policy has suggested that foreign and security policy is indeed an important area of disagreement among political parties (see, e.g., Bjereld and Demker, 2000; Özkeçeci-Taner, 2005; Schuster and Maier, 2006; Devine, 2009; Kaarbo, 2012; Calossi et al., 2013; Clare, 2014; Verbeek and Zaslove, 2015; Pijovic, 2016; Chryssogelos, 2018; Hofmann, 2017). Because foreign policy, including military missions, can be salient to voters and influence voting behaviour (cf. Aldrich et al., 2006; Gartner and Segura, 2008; Clements, 2013), political parties have incentives to court public opinion and distinguish themselves from one another on security issues (cf. Rathbun, 2004; 
Bow and Black, 2008; Clare, 2010; Mello, 2012; Hildebrandt et al., 2013; Joly and Dandoy, 2016). Much of the previous research, however, has focused on single countries or episodes, or on the relationship between ideological factionalism and international conflict. There is yet no comparative analysis of the extent to which parties systematically differ on military operations across countries. This paper addresses this gap by examining the following proposition:

PROPOSITION 1: Decisions on the deployment of armed forces are systematically contested amongst the political parties in a country.

A full exploration of the topic, however, requires going beyond the parties matterargument to examine motivations behind parties' orientations towards military deployments. We are particularly interested in the extent contestation of military missions corresponds to general cleavages that have been identified by scholars of party politics and recent studies on the politicization of international affairs (see below). The most prominent of such cleavages is, of course, the left/right one that emerged during the industrial revolution and remains highly influential to the present day (Lipset and Rokkan, 1967). Koch and Sullivan (2010) argue, for example, that positions on the use of armed force abroad result from positions on social policy because the armed forces and the welfare state compete for the same resources. Therefore, political parties that promote the welfare state tend to oppose large armies, expensive military procurement as well as the actual use of armed force abroad. Studies on the actual use of force find support for a left/right cleavage as 'right governments are more likely to be involved in militarized disputes than are left governments' (Palmer et al., 2004: 13; see also Rathbun, 2004; Arena and Palmer, 2009; Clare, 2010, 2014; Oktay, 2014; Williams, 2014).

Changing values in society, globalization, migration and the emergence of supranational authority have led students of party politics to consider additional cleavages that pit winners of globalization against losers (Kriesi et al., 2008) and/or proponents of post-materialist and cosmopolitan values against traditionalists and communitarians (Zürn and de Wilde, 2016; Hooghe and Marks, 2018). The relevance of this cleavage has been established more broadly for parties' positions on European integration and globalization but has not been examined for military missions. Because military missions of the post-Cold War period are no longer about territorial defence and are more often justified as 'saving strangers' (Wheeler, 2000) from statesponsored violence and repression, the use of armed force may resonate with cosmopolitan values of human security and equality (Rathbun, 2004).

Taken together, we derive two propositions from the literature on party-political cleavages:

PROPOSITION 2: Party-political contestation of military missions is structured by a left/right cleavage with right parties more supportive of such missions than left parties. 
PROPOSITION 3: Party-political contestation of military missions is structured by a post-materialist/cosmopolitan vs. traditionalist/nationalist cleavage with parties scoring high on post-materialism/cosmopolitanism being more supportive of such missions than parties scoring high on traditionalism/nationalism.

Although the left/right as well as the post-materialism/traditionalism cleavage can easily be applied to military missions, students of the partisan theory of public policy (as well as structural theories of international relations) have argued that for security and defence policy, the ideological disposition of governments may be superseded by pressures emanating from the international system. Hans Keman, for example, argued that geopolitical factors are particularly important for defence spending and render domestic politics by and large irrelevant (Keman, 1982: 192). Even though the end of the Cold War might have created more room for political manoeuvre when it comes to wars of choice, 'systemic pressures to cooperate' (Kreps, 2010: 192) remain high. Sarah Kreps argues that in NATO's mission in Afghanistan, political parties chose to forgo electoral gains because they were sensitive to the high reputational costs of defection from a joint intervention (see also Schultz, 2001). In addition, high levels of path dependency and bureaucratic routines make any substantial policy changes to on-going and inherited force commitments very difficult (Goldmann, 1982; Hermann, 1990). However, in contrast to Kreps, who sees not only governing parties but elites in general under pressure to contribute to joint interventions, we argue that such pressures are primarily felt in government and thus expect political parties in government to factor them into the positions they take, whereas parties in opposition remain less constrained from such considerations. This logic is consistent with Lewis' (2017) claim that when in power, political parties tend to become more internationalist and interventionist. Moreover, parties in opposition have a general incentive to present themselves as an alternative to the ones in government and thus to oppose government policies, even on deployment decisions. According to Williams (2014: 112-113), if opposition parties perceive a military mission 'as being unpopular or potentially disastrous, then they will publicly oppose using force' (see also Schultz, 2001). This leads us to our fourth proposition:

PROPOSITION 4: In government, political parties are, ceteris paribus, more supportive of military missions than in opposition.

It should be noted, however, that any test of this proposition may be subject to a selection effect, as the agenda-control is by and large in the hands of the government. ${ }^{2}$ In other words, although governments frequently 'inherit' troop deployments from their predecessors, they still have some room of manoeuver to adjust troop size, mandate, rules of engagement and caveats to the prevailing mood in parliament. Therefore, while

\footnotetext{
${ }^{2}$ We owe this point to one of the anonymous reviewers.
} 
our data show that backbench opposition is not uncommon, especially in the United Kingdom, we do not expect this proposition to be falsified. Nevertheless, taking parties' position in government or opposition into account will act as an important control for testing our other propositions in the multivariate regression below.

\section{Methodology}

To examine the party-political contestation of military missions, we use expert survey data on political parties' positions as well as data from a new data set on parliamentary votes on deployment decisions. The expert survey data come from the two latest rounds of the CHES in 2010 and 2014, which included a question on peace and security missions (Bakker et al., 2015b; Polk et al., 2017). Under the heading 'position towards international security and peacekeeping missions', experts are asked to determine a political party's position on a scale from 0 ('strongly favours COUNTRY troop deployment') to 10 ('strongly opposes COUNTRY troop deployment'). ${ }^{3}$ More than 300 experts mapped the positions of political parties. ${ }^{4}$

As in the previous survey, experts were also asked to map political party positions on a left/right and a gal/tan axis: Experts are asked 'Please tick the box that best describes each party's overall ideology on a scale ranging from 0 (extreme left) to 10 (extreme right)'. On gal/tan, experts are asked: 'Parties can be classified in terms of their views on democratic freedoms and rights. Libertarian or post-materialist parties favour expanded personal freedoms, for example, access to abortion, active euthanasia, same-sex marriage, or greater democratic participation. Traditional or authoritarian parties often reject these ideas; they value order, tradition, and stability, and believe that the government should be a firm moral authority on social and cultural issues' (Bakker et al., 2015b: 144). 0 indicates extreme gal and 10 extreme tan. ${ }^{5}$

Finally, we make use of the notion of party families to cluster parties into groups with shared core values and interests and to examine whether there are significant differences across the main party families. Data on family membership come from CHES. We exclude the Confessional/Protestant, Agrarian and Regionalist/Ethnic party families as well as all parties that are coded as not belonging to any family. Furthermore, we merged the party families Conservatives and Christian Democrats into one category because they occupy comparable positions in the countries we studied in depth. We thus explore differences between the main party families, namely Conservatives/Christian Democrats (criscon), Socialists, Liberals, Greens, Radical Left, and Radical Right.

\footnotetext{
${ }^{3}$ For this article, we have reversed the scale and re-coded the 'international security' variable into a support-mission variable that ranges from 0 (strongly opposes) to 10 (strongly favours).

${ }_{4}$ The 2010 survey covers 237 parties in 28 states, namely all EU states except Cyprus, Luxemburg, and Malta as well as Croatia, Norway, Switzerland, and Turkey. The 2014 survey covers 268 parties, including those from Cyprus, Luxemburg, and Malta (see Bakker et al., 2015a).

${ }^{5}$ For a detailed discussion of the survey's validity and reliability see Hooghe et al. (2010).
} 
The merits and shortcomings of expert survey data in comparison to the data of the manifesto research group (Volkens et al., 2013) have been extensively discussed. ${ }^{6}$ Our decision to use the CHES expert survey data does not result from taking sides in this dispute but is motivated by the data's validity for the purpose of this paper: whereas the CHES data specifically include a question about 'peace and security missions', the manifesto data handle the rather broad categories 'military: positive', 'military: negative', and 'peace: positive'; additionally, manifesto coders are instructed to interpret 'military' to include defence spending, force levels, rearmament, and treaty obligation. Thus, for our purposes, we consider the CHES question to capture this study's attempt at measuring party-political contestation over military missions more precisely.

For the deployment votes, we compiled a new database, Parliamentary Deployment Votes, in which we collected data on a total of 183 roll-call votes ${ }^{7}$ in plenaries for the period between 1991 and August 2016 in France, Germany, Spain, and the United Kingdom. ${ }^{8}$ These four countries have played important roles in military missions but represent different constitutional traditions and political-strategic cultures. Together, these four countries account for approximately two-thirds of defence spending in the EU. Across the four countries under study, the practice of voting on military missions differs enormously (Wagner et al., 2017). The German Bundestag has ex ante approval rights for military missions due to a Federal Constitutional Court ruling in 1994 and has voted more than 140 times since, partly because extensions, changes in mandate or troop levels require parliamentary approval. The French parliament was only endowed with ex post voting rights on military operations through the constitutional reform of 2008 (Ostermann, 2017). In Spain, parliamentary control of military missions had become an issue in the wake of the 1999 Kosovo intervention, but it was only after the highly contested involvement of Spain in the 2003 Iraq war that an ex ante veto power was introduced, by means of an Organic Law, in 2005. In the United Kingdom, deployment votes are rare because of former royal prerogatives but have become more common in the wake of the 2003 Iraq War and have even led some to see this as a new

\footnotetext{
${ }^{6}$ See the contributions to the special symposium 'Comparing Measures of Party Positioning: Expert, Manifesto, and Survey Data' in Electoral Studies 2007 as well as Gemenis (2013). One of the common criticisms on the use of expert survey data is that there is a risk of endogeneity, since experts might factor a party's position on military missions into their assessment of its position on the left/right and gal/tan dimension and vice versa. However, we consider this risk to be limited because experts of the Chapel Hill survey are typically from comparative politics with a prime interest in economic policy and the welfare state, rather than foreign policy. Their left/right and gal/tan assessment is thus likely to be informed primarily from domestic political issues.

7 Strictly speaking, the votes we study are not roll-call votes because individual MPs are not called to indicate their vote (as practiced in the US Congress). Instead, individual MPs' votes are usually recorded electronically or by way of voting cards (for an overview see Saalfeld, 1995).

${ }^{8}$ All voting data can be retrieved from www.deploymentvotewatch.eu and the Harvard dataverse at https://dataverse.harvard.edu/dataset.xhtml?persistentId=doi:10.7910/DVN/60RZCC. An overview can be found in the Appendix to this paper.
} 
convention (Strong, 2014; Mello, 2017). ${ }^{9}$ To make deployment vote data comparable across parties and reflect the interest in government-opposition dynamics, we calculate averages of no-votes per party during a given legislative term (the full data set contains disaggregated and aggregated data on every single vote). ${ }^{10}$ Our coding of party families is based on the CHES coding.

The data on deployment votes also allows us to investigate the extent of partypolitical contestation of deployment decisions as compared to other matters. To capture the degree of dissent within parliament as a whole, we calculate an AI that Hix et al. (2005) originally developed to measure party cohesion in the European Parliament. ${ }^{11}$ The AI equals 1 when all MPs vote together and it equals 0 when they are equally divided between the voting options. This index has become an established measure to assess the unity of groups within legislatures - mostly political parties, but in studies of the European Parliament also members of the same country. To our knowledge, the AI has not been used to measure degrees of consensus within a parliament as a whole, ${ }^{12}$ most likely because the recording of individual votes already is a sign of contestation; uncontroversial parliamentary decisions are often adopted without the time-consuming recording of individual votes. Moreover, parliaments differ enormously in the ways they vote, with some often recording votes and others doing so only rarely (Saalfeld, 1995). Hence, recorded votes may be a very unrepresentative sample of all votes in a parliament (Carruba et al., 2008). Yet for the purposes of this study, the AI allows an assessment of the degree of dissent on military mission votes and on any other matters in our four countries. This allows us to examine to what extent party politics indeed stops at the water's edge. ${ }^{13}$

\footnotetext{
9 The record of parliamentary involvement is, however, inconsistent, even in recent years. The 2010 vote to continue deployments in Afghanistan, for example, occurred nine years after the introduction of British troops there. The 2011 vote on the use of force against Libya was post hoc, after the mission had begun, and in 2013, the UK government deployed military assets and military personnel (in non-combat roles) to Mali without a parliamentary vote.

${ }^{10}$ In the subsequent analyses, we exclude one vote in the Bundestag, which was about Germany's contribution to 'Operation Enduring Freedom' in Afghanistan and at the same time a vote of confidence for Chancellor Schröder and his coalition of Social Democrats and Greens. The data clearly demonstrate that MPs' voting behaviour was driven by the confidence vote, not the simultaneous question of sending troops to Afghanistan. Although the CDU/CSU and the FDP supported the mission, not a single MP from these parties in the opposition voted in favour of the government motion. With 326 votes against and 336 in favour, it was the closest deployment vote in the Bundestag thus far.

11 The precise formula $A I_{i}=\frac{\max \left\{Y_{i}, N_{i}, A_{i}\right\}-\frac{1}{2}\left[\left(Y_{i}+N_{i}+A_{i}\right)-\max \left\{Y_{i}, N_{i}, A_{i}\right\}\right]}{Y_{i}+N_{i}+A_{i}}$ is:

12 Students of the US Congress typically measure bipartisanship as 'the extent to which majorities or near majorities of both parties in Congress vote together' (Kupchan and Trubowitz, 2007: 11). The AI, however, is a much more precise measure of dissent. Hix et al. calculated an AI for the entire EP only in order to better gauge the relative unity of political parties and national delegations.

${ }^{13}$ For the calculation of the AI for recorded votes on other business, data on Germany and on France are taken from the homepages of the Bundestag (https:/www.bundestag.de/dokumente/datenhandbuch/ datenhandbuch_archiv, last accessed 14 July 2016) and the Assemblée nationale (http://www2.assembleenationale.fr/scrutins/liste/\%28legislature\%29/14, last accessed September 2016), data on the UK from Firth and Spirling (2003) and from publicwhip (http://www.publicwhip.org.uk, last accessed September 2016). Because voting data for the Spanish Congreso had to be imputed manually, we decided to limit our sample
} 
A final note of caution applies to both data sources: neither the CHES nor the deployment vote data distinguish between different types of missions. Such differentiation would be particularly welcome for testing our third proposition on the impact of a party's gal/tan position because we can safely assume that humanitarian missions are more appealing to parties at the gal-end of the spectrum than counter-terrorism missions, whereas the opposite applies to parties at the tan-end of the spectrum. Except for a few ideal-typical cases, however, military interventions are notoriously difficult to categorize. Governments typically evoke a combination of justifications for a military intervention, often blending humanitarian motivations with self-defence (as was the case in the 2003 Iraq war and the 2014 strikes against Daesh) to appeal to various segments of society. The relative weight of these justifications is often at the center of the party-political debates that we study in this paper. Any classification of military interventions would therefore also be in tension with our point of departure that foreign and security policy is politically contested. For the purpose of this paper then, we explore party positions on military missions in general.

\section{Findings}

\section{Degree of contestation: does politics stop at the water's edge?}

Table 1 contains our calculation of the AI. It shows the average degree of contestation of military missions compared to other business for every legislative term under study. Two findings are worth highlighting: first, degrees of contestation vary significantly across countries and legislative terms. They range, for instance, from high contestation on military missions with an AI equalling 0.46 for the Cameron II government in the United Kingdom to low contestation with an AI equalling 0.98 for the Zapatero II government in Spain. This means that military missions are neither uncontroversial nor highly contested as such. For France, contestation moves between AIs of 0.66 (Sarkozy presidency) and 0.94 during François Hollande's term. Germany gives testament to a similar spread with AIs ranging from 0.62 (highest contestation) to 0.95 (lowest). Whereas in Spain, decisions are highly consensual and the number of novotes of the right-wing Partido Popular (PP) and the left Partido Socialista Obrero Español (PSOE) are negligible, in the United Kingdom, deployment votes have been much more controversial. The second finding is that levels of contestation of military missions in all four countries are clearly lower than those for other legislative business. In the Zapatero II government in Spain cited above, the AI for other business equals 0.68 , a considerable difference of 0.3 with the military mission AI. In France during Hollande's term (2012-2017), the difference between mission AI (0.94) and other business-AI (0.54) is even larger, reflecting the majority's split on many policy

to votes on adopted legislative acts and to exclude votes on amendments and non-legislative business. The data were retrieved from http://www.congreso.es/portal/page/portal/Congreso/Congreso/Iniciativas/ LeyesAprob, last accessed 16 September 2016. 
Table 1. Agreement Indexes

\begin{tabular}{|c|c|c|c|c|c|}
\hline \multirow[b]{2}{*}{ Country } & \multirow[b]{2}{*}{ Term } & \multicolumn{2}{|c|}{ Votes on military missions } & \multicolumn{2}{|c|}{ Other votes } \\
\hline & & Agreement Index & $N$ & Agreement Index & $N$ \\
\hline \multirow[t]{3}{*}{ France (only AN) } & Mitterrand & 0.89 & 1 & n.a. & n.a. \\
\hline & Sarkozy & 0.66 & 2 & 0.51 & 694 \\
\hline & Hollande & 0.94 & 4 & 0.54 & 1267 \\
\hline \multirow[t]{7}{*}{ Germany } & Kohl IV & 0.62 & 2 & 0.48 & 127 \\
\hline & Kohl V & 0.70 & 5 & 0.41 & 175 \\
\hline & Schröder I & 0.86 & 15 & 0.53 & 147 \\
\hline & Schröder II & 0.95 & 16 & 0.42 & 86 \\
\hline & Merkel I & 0.78 & 32 & 0.69 & 144 \\
\hline & Merkel II & 0.69 & 38 & 0.42 & 237 \\
\hline & Merkel III & 0.77 & 40 & 0.71 & 114 \\
\hline \multirow[t]{3}{*}{ Spain } & Zapatero I & 0.96 & 1 & 0.73 & 107 \\
\hline & Zapatero II & 0.98 & 3 & 0.68 & 83 \\
\hline & Rajoy I & 0.92 & 6 & 0.54 & 134 \\
\hline \multirow[t]{3}{*}{ United Kingdom } & Blair & 0.6 & 1 & 0.55 & 1246 \\
\hline & Cameron I & 0.76 & 4 & 0.5 & 1226 \\
\hline & Cameron II & 0.46 & 1 & 0.48 & 319 \\
\hline
\end{tabular}

issues with its own president, compared to high multi-partisan support for military missions. ${ }^{14}$ The only exception to this finding is the Cameron II cabinet. The average $\mathrm{AI}$ in this case, however, is based on a single vote (on using force against Daesh). In general, though, the AI shows that politics may not stop at the water's edge but it tends to become less contested.

While the AI demonstrates that deployment decisions are indeed contested, it does not provide any additional information of where dissent originates. For a better understanding of the pattern of contestation of military missions, we thus examine whether political parties systematically disagree about deployments. We first use the CHES data on parties' support for military missions. ${ }^{15}$

As Figure 1 visualizes, and as the ANOVA analysis in Table 2 demonstrates, party families systematically differ in the degree to which they favour their country's participation in peace and security missions, as stated in Proposition 1. As a comparison of the standard deviations shows, differences within most party families

\footnotetext{
${ }^{14}$ The little degree of contestation during President Hollande's term also reflects the 2015 terrorist attacks in France and its (positive) impact on national unity. These attacks increased support for the broadscale military action against Daesh in Iraq and Syria, facing an all-party minimum of no-votes of $0.76 \%$. The other two missions extended in parliament during Hollande's term were the anti-terror mission in Mali and the stabilization force for the Central African Republic, countries traditionally central to French African policies, and both passed without a single no-vote.

${ }^{15}$ Data on party families are made available in the 'trendfiles' (Bakker et al., 2015b; Polk et al., 2017), which, in contrast to the data used for Figures 1 and 2, exclude political parties from Norway, Switzerland, and Turkey. In addition, political parties from Cyprus, Luxemburg, and Malta are missing for 2010. To maximize comparability, we manually excluded them for 2014 as well.
} 


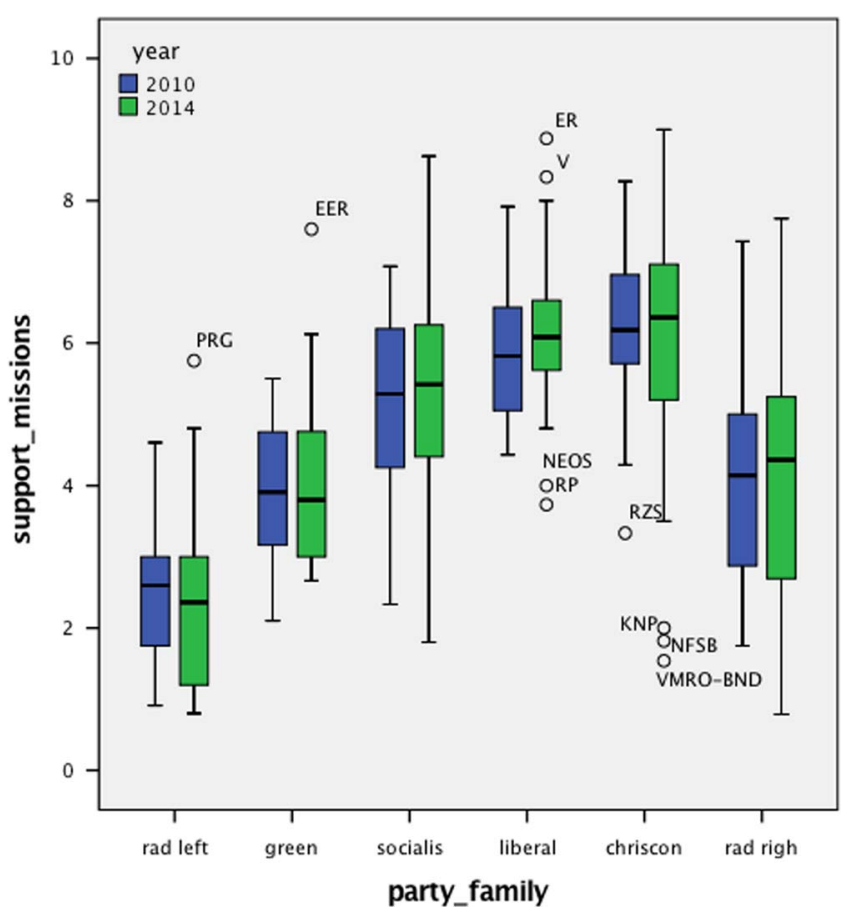

Figure 1 Boxplot of party families' support for peace and security missions. PRG=Parti radical de gauche (France); EER = Erakond Eestimaa ohelised (Estonia); ER = Eesti Reformierakond (Estonia); $\mathrm{V}=$ Venstre (Denmark); NEOS $=$ Das neue Österreich (Austria); RP = Twój Ruch (Poland); RZS = Red, zakonnost i spravedlivost (Bulgaria); KNP=Kongres Nowej Prawicy (Poland); NFSB = Natsionalen Front za Spasenie na Bulgaria (Bulgaria); VMRO$\mathrm{BND}=\mathrm{VMRO}-$ Bulgarsko Natsionalno Dvizhenie (Bulgaria).

increased, thus pointing to higher levels of contestation. Green parties are more supportive than radical-left parties, and socialist parties are more supportive than green and radical-left ones. A notable exception is the French Parti radical de gauche (PRG), which CHES experts gauged as more supportive than the Greens. Support is highest amongst Liberals and Christian Democrats/Conservatives, with some outliers in Central and Eastern European countries. The Radical Right is about as supportive as the Greens. Although the boxplot shows considerable variation within party families, the ANOVA analysis reported in Table 2 demonstrates that differences between party families are statistically highly significant. The data also suggests that the gap between the Radical Left as the main party family most consistently opposing peace and security missions and the parties of the centre is widening, rather than narrowing.

Our collection of deployment votes allows us to further examine whether a similar pattern of contestation can be observed in actual votes on military missions. Figure 2 visualizes the average share of no-votes during a legislative term across party families. Figure 2 supports our first proposition that the deployment of armed forces is 
Table 2. ANOVA analysis of support for peace and security missions across party families

\begin{tabular}{llll}
\hline \hline Family & $N$ & Mean & Std. dev. \\
\hline Radical Right & & & \\
2014 & 20 & 4.14 & 1.836 \\
2010 & 21 & 4.17 & 1.540 \\
Conservatives and Christian Democrats & & & \\
2014 & 51 & 6.07 & 1.592 \\
2010 & 43 & 6.23 & 1.078 \\
Liberal & & & \\
2014 & 36 & 6.18 & 1.082 \\
2010 & 35 & 5.87 & 0.941 \\
Socialist & & & \\
2014 & 35 & 5.34 & 1.422 \\
2010 & 29 & 5.21 & 1.324 \\
Green & & & \\
2014 & 19 & 4.12 & 1.307 \\
2010 & 17 & 3.92 & 0.948 \\
Radical Left & & & \\
2014 & 22 & 2.49 & 1.359 \\
2010 & 21 & 2.58 & 1.003 \\
\hline \hline
\end{tabular}

$P<0.001$ between-group comparison for both 2010 and 2014

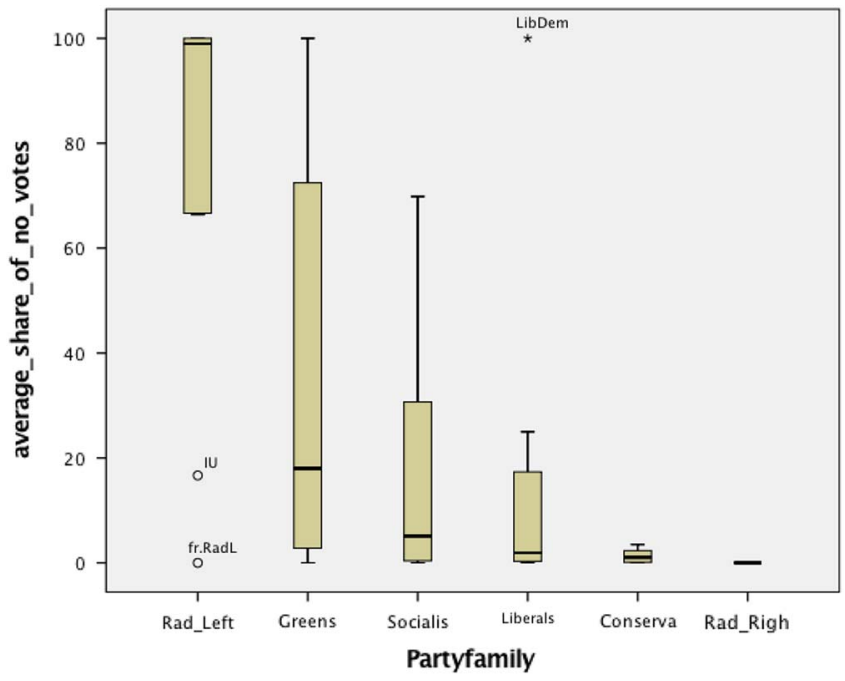

Figure 2 Average share of no-votes across party families in the four countries under study. $\mathrm{IU}=$ Izquierda Unida (Spain); fr. RadL = Parti communiste français (PCF) and Parti radical de gauche (PRG) combined; LibDem = Liberal Democrats (United Kingdom). 
systematically contested amongst political parties. The figure shows that differences across party families are even more pronounced in actual votes. The boxes and whiskers also indicate, however, that there is a considerable spread: radical-left, green, and liberal parties have all voted both unanimously for and against military deployments throughout a particular legislature. Of course, whether a party is in government or in opposition impacts on its voting behaviour. In France, for example, radical-left PRG lawmakers are often part of left-wing majorities or part of the government and therefore vote in line, contrary to the other parties in their family. In the United Kingdom, all Liberal MPs voted against the Iraq war in 2003 but most of them voted for interventions in Afghanistan, Libya, Syria, and Daesh in Iraq when in government. ${ }^{16}$ In Spain, the radical-left Izquierda Unida (IU) has never given its approval to any mission but has abstained on several occasions - mainly EU maritime surveillance and training operations and UN-led missions. IU's choice for abstention (instead of voting directly against) was most frequent during the Zapatero II term, when Socialists held a minority government, thus often dependent on the votes of IU and other regional parties. ${ }^{17}$ In Germany, Social Democrats and Greens voted in favour of military missions when in government but were less supportive when in opposition. We will come back to the impact of being in government or opposition when running a multivariate regression analysis below.

Differences in support across party families are, however, by and large akin to those in Figure 1: support is lowest among parties of the Radical Left, followed by Greens and Socialists. Christian Democrats and Conservatives, as well as Liberals, are generally supportive of military deployments with considerably decreasing shares of no-votes. Voting data differ from CHES data as regards the Radical Right: whereas the experts have gauged them to be unsupportive of peace and security missions, our voting data reveal that they never voted against any deployment decision. However, the empirical basis for this finding is very small: in the four countries under study, only two MPs of the Front national in the 2012-2017 legislature of the Assemblée nationale and a single MP of the United Kingdom Independence Party (UKIP) in the 2015-2017 House of Commons represent radical-right parties; additionally, these MPs took only part in a small number of votes.

16 The 2013 vote on Syria was unusual in a number of other ways as well (Kaarbo and Kenealy, 2016). MPs actually voted on two motions - one supported by the Government (reflected in our data) and one introduced by Labour. There were only minor differences between the two motions; both called for a second vote before military action. The irony of the vote was that although most MPs supported the use of force (by voting for one motion or the other), since no motion gained majority support, UK participation in military strikes against Syria was taken off the table. This outcome was unprecedented as it was the first defeat for a British PM on a security matter since 1782, when Lord North, then PM, lost a vote of confidence following the British defeat at Yorktown. In 2014, the same parliament that was divided over Syria solidly supported force against Islamic State in Iraq, although here again, opposition did come from the left (some in Labour and the Green MP).

${ }^{17}$ Regional left-wing parties represented in Congress (Esquerra Republicana de Catalunya, Bloque Nacionalista Galego, Nafarroa Bai/Geroa Bai, and Compromis) have also tended to vote against military operations or abstained, the latter option being also more frequent with Socialist governments. 


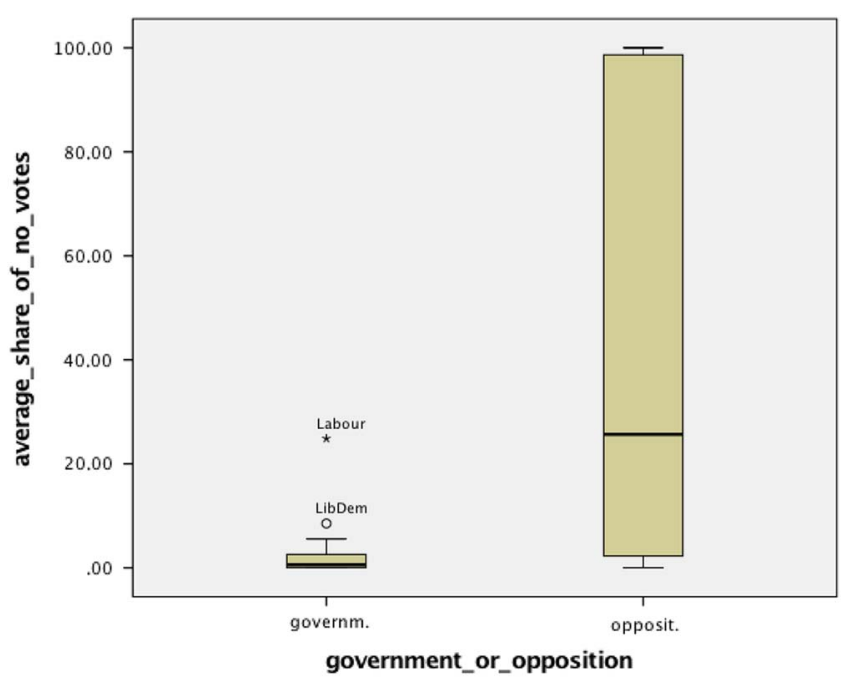

Figure 3 Comparison of average share of no-votes between parties in government and parties in opposition in the four countries under study.

Taken together, expert survey and voting data demonstrate that military missions are contested among political parties. To be sure, the degree of dissent tends to be lower than for other, mostly domestic, issues, which suggests that the politics stops at the water's edge idiom impacts on the politics of military deployments. By clustering political parties into families, we demonstrate, however, that political parties differ systematically on the use of force abroad: expert survey and voting data concur that Christian Democrats/Conservatives are more supportive than Socialists, who are in turn more supportive than the Greens and the Radical Left. The two data sources only differ as regards the Radical Right: whereas experts find it almost as opposed to military missions as the Greens, voting data suggest they are the most supportive of all parties. Because of their limited representation in parliament, however, the finding on the Radical Right is far from robust and will require further research in the future.

\section{Drivers of contestation: old or new politics?}

Having demonstrated that military missions are politically contested, we now turn to the question of what motivates contestation. Specifically, we examine the three possible drivers discussed above, namely a party being either in government or opposition (Proposition 4), its position on the left/right axis (Proposition 2) and on the gal/tan axis (Proposition 3).

We begin by examining the impact of being in government or in opposition. Figure 3 demonstrates that there is indeed strong evidence for our fourth proposition: membership in government has a statistically significant $(P<0.001)$ impact on 
the number of no-votes when parliament decides on military deployments: the average number of no-votes per party per legislature differs between $42.8 \%$ (in opposition) and $2.4 \%$ (in government). ${ }^{18}$ Outliers all come from the United Kingdom: In 2003, 84 out of 338 Labour MPs voted against their own government on the Iraq war. Whilst part of the Cameron/Clegg government, Liberal Democrats mostly voted with the government but the average number of no-votes increased: 10 out of 42 Liberal Democrats voting against their own government on a possible Syrian intervention in 2013.

To be sure, the enormous differences in voting against military missions might also result from a selection effect: Die Linke, for example, may vote against deployments because it is free to do so in opposition, but one can also argue that it is in opposition because it fundamentally opposes a key element of German security policy. Looking at political parties that move in and out government, however, suggests that voting behaviour is indeed partly driven by the constraints of being in office: the average share of no-votes amongst German Social Democrats and Greens dropped dramatically when in government (1998-2005) and rose again once back in opposition. In France, whereas 175 Socialists in the Assemblée nationale and 87 socialist senators voted against the Afghanistan mission extension in 2008 whilst in opposition, only one Socialist in the Assemblée nationale voted against Libya in 2011, and no socialist senator at all when the Parti Socialiste (PS) was in government.

The CHES data on political parties' left/right and gal/tan positions are particularly useful to examine whether contestation of military missions is driven by an overarching ideological cleavage, that is whether contestation reflects different fundamental values across the political spectrum. A previous study used data from the 2010 CHES to demonstrate that party-political contestation over military missions follows a curvilinear left/right pattern (Wagner et al., 2017). The 2014 CHES data allow us to examine whether this finding holds for 2014 as well. Figure 4 demonstrates that it does, in line with our second proposition. In terms of the left/ right cleavage, the correlation is indeed curvilinear: using a quadratic model, the correlation is statistically significant at the 0.001 level with a $r^{2}$ of 0.36 (2014). ${ }^{19}$ Support for peace and security missions increases as one moves from the left to the centre right and declines again towards the radical right.

Figure 5 shows that support for military missions also differs along the gal/tan scale, as stated in our third proposition: Political parties that score high on being either green/alternative/libertarian or traditional/authoritarian/nationalist are both less supportive of deploying armed forces than those in the middle of this scale. The 2014 data in Figure 5 demonstrate that the gal/tan scale is a highly significant predictor but explains less variation than the left/right scale (for 2014, $r^{2}$ equals 0.15). Compared to 2010, the differences in variation explained have declined

18 This test includes lower chambers only and thus excludes the French Sénat.

19 A linear model is also statistically highly significant at the 0.001 level but the $r^{2}$ is much lower $(0.165$ in 2014). 


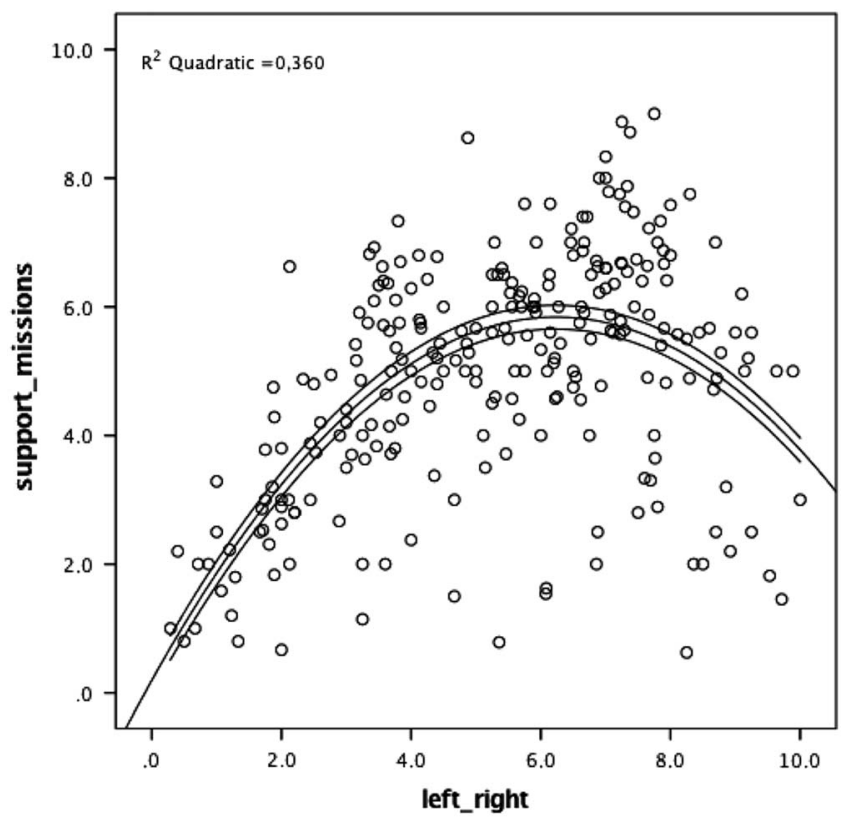

Figure 4 Mapping of political parties' positions on military missions and on a left/right scale, 2014.

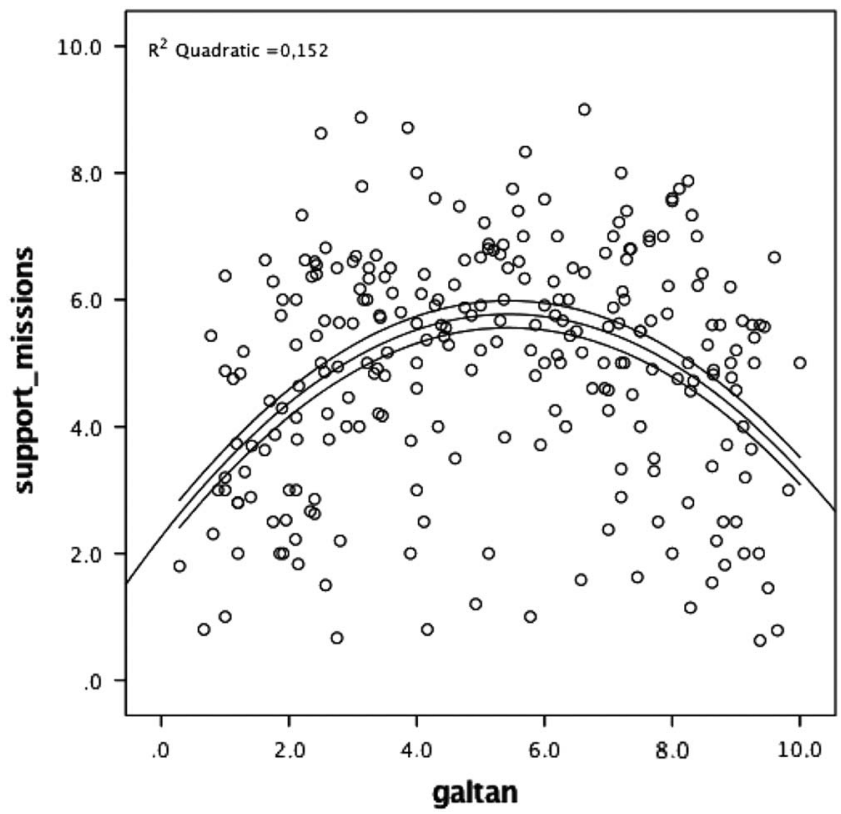

Figure 5 Mapping of political parties' positions on military missions and on a GAL/TAN scale, 2014. 


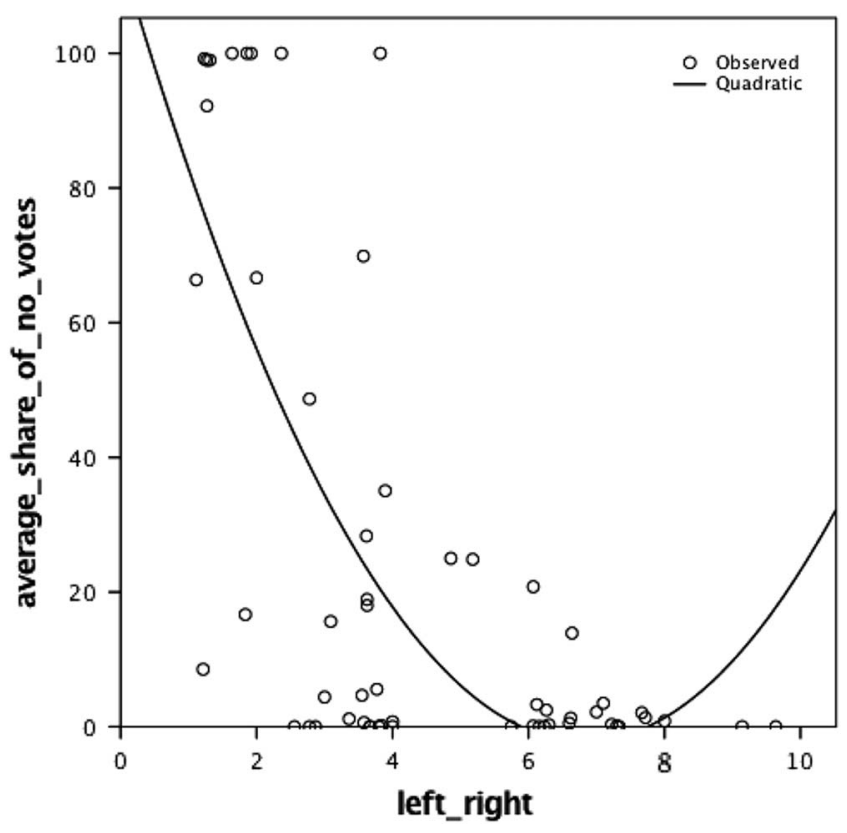

Figure 6 Mapping of political parties' positions on a left/right scale and share of no-votes in parliamentary deployment votes [we attribute 2010 Chapel Hill Expert Survey (CHES) scores for left/right (Figure 6) and GAL/TAN (Figure 7) to the legislative terms of Merkel II (20092013), Zapatero II (2008-2011), Sarkozy (2007-2012), and the British House of Commons votes in the period 2010-2013. 2014 CHES scores are attributed to Merkel III (2013-2017), Rajoy I (2011-2015), Holland (2012-2017), and the House of Commons votes in 2014 and 2015. Christian Democrats in Germany, Liberals and Radical Left in France consisted of two or more political parties whose CHES scores were then weighted according to their share of seats in parliament].

(0.36/0.15 for 2014 vs. $0.35 / 0.11$ for 2010$)$. Additional data from future surveys are needed to judge whether this is a significant trend.

Again, our voting data allow us to triangulate the drivers of political contestation. The actual deployment votes in our four countries confirm the importance of the left/right cleavage. However, in contrast to the CHES data, the actual votes suggest a linear relationship, with the Radical Right in France and with the UK supportive of military deployments. Figure 6 visualizes political parties' positions on the left/ right scale and their average share of no-votes in parliamentary deployment decisions. The scatterplot shows that the share of no-votes within a political party decreases as one moves from the (far) left to the (far) right of the political spectrum, again in line with our second proposition. Parties of the Radical Left, such as Die Linke in Germany and IU in Spain, sometimes voted unanimously against military deployments. The only time some MPs of Die Linke ever voted in favour of a military mission in Germany was when the Bundeswehr was called in to support the 


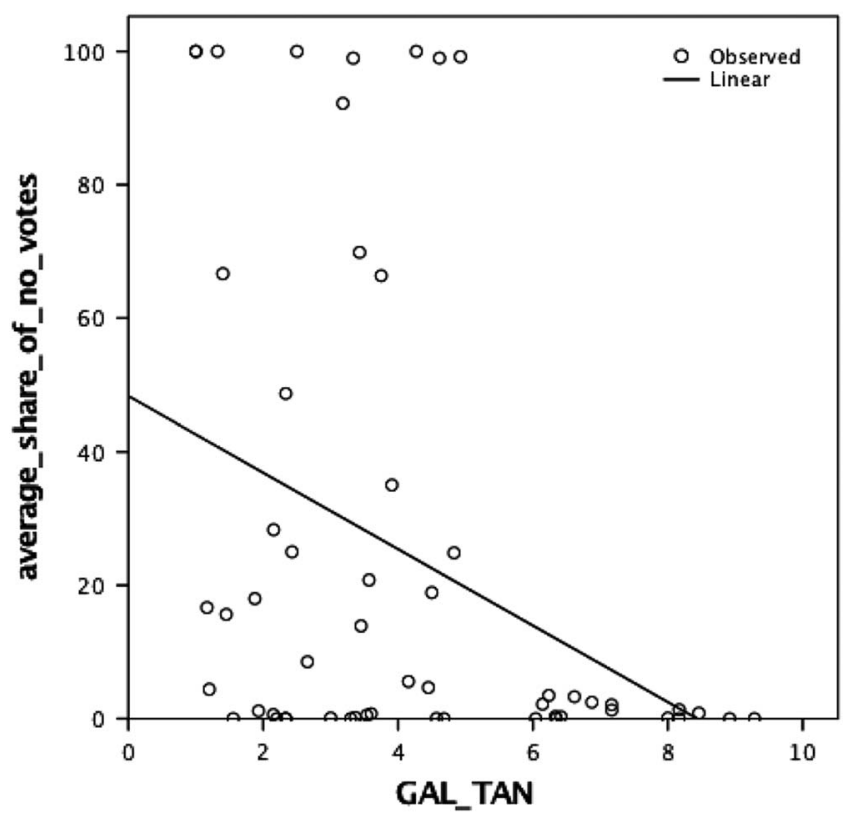

Figure 7 Mapping of political parties' positions on a GAL/TAN scale and share of no-votes in parliamentary deployment votes.

destruction of chemical weapons in Syria in 2014. The Greens were the traditional home of the German peace movement and initially shared the Radical Left's principled opposition to military missions. Even though the Bundeswehr's early deployments were non-combat missions, the Greens consistently voted against them during Helmut Kohl's fourth government between 1990 and 1994. Starting after the 1994 elections, however, the Greens embarked on a painful process of recalibrating their position on the use of force (Vollmer, 1998). Spurred on by the future Foreign Minister Fischer, this process was highly conflictual but also signalled to the Social Democrats that a possible coalition would be feasible. When in government between 1998 and 2005, the share of no-votes dropped indeed but remained consistently above the share amongst Social Democrats. Back in opposition (from 2005 on), the share of no-votes rose again but not to the level of the pre-government period. A closer look shows that the Greens are especially divided over the Afghanistan missions. At the same time, their opposition against the Bundeswehr's contribution to the EU-led maritime operation against human trafficking and their support for the missions in Darfur, South Sudan, Bosnia, and Kosovo have been unanimous.

Figure 7 visualizes political parties' positions on the gal/tan scale and their average share of no-votes in parliamentary deployment decisions. The scatterplot demonstrates that the average share of no-votes decreases as one moves from the green/ alternative/libertarian end of the spectrum to the traditional/authoritarian/nationalist 
Table 3. Multivariate regression analysis

\begin{tabular}{lccccc}
\hline \hline & Model 1 & Model 2 & Model 3 & Model 4 & Model 5 \\
\hline Left/right & $-0.634^{* * *}$ & & $-0.600^{* * *}$ & & $-0.808^{* * *}$ \\
GAL/TAN & & $-0.371^{* * *}$ & & $-0.371^{* * *}$ & 0.264 \\
Gov/Opp & & & $-0.425^{* * *}$ & $-0.473^{* * *}$ & $-0.409^{* * *}$ \\
\hline \hline
\end{tabular}

$N=56$; coefficients are standardized

$\because * P<0.01$.

end, as stated in our third proposition. A closer look shows that political parties' positions on the gal/tan dimension often resemble those on the left/right axis: UKIP and the Front national mark the far end on both scales; on the other end of the spectrum, radical-left and green parties switch positions but both remain in the left half of the spectrum. Yet, a curve estimation of the left-right and gal/tan models demonstrates that the correlation of the left-right model with support for deployments is far stronger than for the gal/tan model. In the linear model, $38 \%$ of the variation in voting is explained by the left-right scale; in the cubic model, more than $50 \%$ of variation is explained. For gal/tan, only around $13 \%$ of the variance in support for missions is explained by the gal/tan scale (for gal/tan, linear and cubic models hardly differ).

The figures thus far provide evidence for both governmental constraints and ideological contestation. In order to gauge the relative predictive power of government/opposition, left/right and gal/tan, we run a multivariate regression analysis with the average share of no-votes as dependent variable. We test several models to assess the impact of these variables on their own and in combination with each other. Table 3 shows that a party's left/right score has a strong and highly significant effect on a party's average share of no-votes in a legislative term. The effect is strongest when controlling for both gov/opp and gal/tan but the effect is strong and statistically significant across different models. The predictive power of a party's position on the gal/tan is smaller and melts away if left/right is controlled for. The effect of gov/opp is also strong but remains weaker than left/right. It is statistically highly significant in any combination with other predictors. Taken together, therefore, we can conclude that actual party behaviour in parliament is driven by both governmental constraints and ideological contestation, especially as connected to parties' positions on the left/right scale.

\section{Conclusion}

Decisions on the use of armed force are at the heart of security and defence policy, an issue area that has remained underexplored by students of party politics. Although deployment decisions have often been framed in terms of a national interest that transcends particular interests, our analysis shows that they are not exempted from party-political contestation: political parties in Europe systematically disagree on 
whether their country should participate in peace and security missions. Moreover, in line with recent studies on politicization of European integration and international affairs, our analysis of the CHES data indicates that differences in support for military operations across parties are growing over time rather than narrowing.

Whereas the CHES data provide us with expert judgments on parties' general positions on military missions, our new Parliamentary Deployment Votes Database allows us to gain additional insights into how political parties act when asked to support an actual mission in parliament. Our analysis shows that being part of the governmental majority or of the opposition has a big impact on a party's actual voting. However, the government/opposition logic is not the most important factor in explaining differences in voting behaviour. Instead, the strongest predictor of how supportive a political party is of actual military deployments is its position on the left/right axis: support is lowest amongst parties of the Radical Left and increases as one moves along the left/right axis to the Greens, the Social Democrats, the Liberals, and the Christian Democrats and Conservatives.

The findings thus indicate that debates on the use of armed forces in Europe are still structured around the 'old' welfare-oriented cleavage, rather than a 'new' culturalist cleavage emerging in response to the twin dynamics of globalization and Europeanization. However, evidence for the positioning of parties on the Radical Right is still inconclusive. The CHES data suggest that they are less supportive of military missions than the parties of the centre and the moderate right. In contrast, deployment vote data suggest high levels of support but should be treated with great caution as they are derived from very few MPs and votes in just two countries. Whether support for peace and security missions relates to the left/right axis in a linear or curvilinear way, therefore, remains an item for further research.

Another item for future research is the disaggregation of military missions. The CHES data inquire about peace and security missions in general and the deployment vote data report averages per legislative term, thus lumping together peacekeeping, peacemaking, humanitarian intervention, and self-defence. Our analysis demonstrates that this is not necessarily a problem because systematic party-political differences on peace and security missions in general clearly exist and are just as meaningful as differences over, for example, European integration in general. Nevertheless, disaggregating deployments in terms of purpose, justification under international law, risks for troops, international organization in charge, etc. is a promising way to gain additional insights into patterns and drivers of contestation of military missions.

Overall, this study contributes to the long-standing tradition of research on the domestic politics of international conflict but follows new ways. We demonstrate that the party system is an important site of contestation as regards military missions, thus redressing the relative lack of research on parties as important actors in security policy. Going beyond the parties matter-claim, this study advances research on political parties and foreign policy by unpacking the different ideological dimensions as well as political incentives and logics driving parties' positions and 
voting on military missions. This analysis not only bridges previous research from international relations on politicization, from comparative politics on political parties, and from foreign policy analysis on domestic politics processes, but our findings also connect perspectives on ideologies and ideas with more institutional approaches. Political parties, as carriers of ideologies housed in institutionalpolitical contexts, are an ideal subject to examine these connections.

\section{Acknowledgments}

The authors received valuable comments and suggestions from Sebastian Bödeker, Brian Burgoon, Aron Buzogany, Pieter de Wilde, Benjamin Faude, Piet Hays Gries, Jonas Hagmann, Dieuwertje Kuijpers, Matthias Kranke, Onawa Lacewell, Thomas Malang, Ignacio Molina, Andrew Neal, Kai Oppermann, Trineke Palm, Brian Rathbun, Christian Rauh, Tapio Raunio, Mathew Stephen, Alexandros Tokhi, Paul van Hooft, Gijsbert van Iterson Scholten, Mariken van der Velden, Michael Zürn, members of the University of Edinburgh IR Research Group, and the anonymous reviewers.

\section{Supplementary material}

To view supplementary material for this article, please visit https://doi.org/10.1017/ S1755773918000097

\section{References}

Aldrich, J.H., C. Gelpi, P. Feaver, J. Reifler and K. Thompson Sharp (2006), 'Foreign policy and the electoral connection', Annual Review of Political Science 9(1): 477-502.

Arena, P. and G. Palmer (2009), 'Politics or the economy?: Domestic correlates of dispute involvement in developed democracies', International Studies Quarterly 53(4): 955-975.

Auerswald, D.P. (1999), 'Inward bound: domestic institutions and military conflicts', International Organization 53: 469-504.

Bakker, R., C. de Vries, E. Edwards, L. Hooghe, S. Jolly, G. Marks, J. Polk J, J. Rovny, M. Steenbergen and M. Vachudova (2015a), 2014 Chapel Hill Expert Survey. Version 2015.1, Chapel Hill, NC: University of North Carolina, Retrieved from chesdata.eu.

Bakker, R., E. Edwards, L. Hooghe, S. Jolly, G. Marks, J. Polk J, J. Rovny, M. Steenbergen and M. Vachudova (2015b), 'Measuring party positions in Europe: The Chapel Hill expert survey trend file, 1999-2010', Party Politics 21(1): 143-152.

Balfour, R., J. Emmanouilidis, C. Fieschi, H. Grabbe, C. Hill, T. Lochocki, M. Mendras, C. Mudde, M.K. Niemi, J. Schmidt and C. Stratulat (2016), Europe's Troublemakers. The Populist Challenge to Foreign Policy, Brussels: European Policy Centre.

Bjereld, U. and M. Demker (2000), 'Foreign policy as battlefield: a study of national interest and party motives', Scandinavian Political Studies 23(1): 17-36.

Boix, C. (2007), 'The emergence of parties and party systems', in C. Boix and S.C. Stokes (eds) Handbook of Comparative Politics, Oxford, UK: Oxford University Press, pp. 499-521.

Bornschier, S. (2010), 'The new cultural divide and the two-dimensional political space in Western Europe', West European Politics 33(3): 419-444. 
Bow, B. and D. Black (2008), 'Does politics stop at the water's edge in Canada?', International Journal 64(1): 7-27.

Buzan, B., O. Wrver and J. de Wilde (1998), Security: A New Framework for Analysis, Boulder, CO: Lynne Rienner.

Calossi, E., F. Calugi and F. Coticchia (2013), 'Peace and war in political discourse of Italian Marxist and post-Marxist Parties', Contemporary Italian Politics 5(3): 309-324.

Cantir, C. and J. Kaarbo (2016), 'Unpacking ego in role theory: vertical and horizontal role contestation and foreign policy', in C. Cantir and J. Kaarbo (eds). Domestic Role Contestation, Foreign Policy, and International Relations, London: Routledge, pp. 1-22.

Carruba, C., M. Gabel and S. Hug (2008), 'Legislative voting behavior, seen and unseen: a theory of roll-call vote selection', Legislative Studies Quarterly 33(4): 543-572.

Chan, S. and W.S. Safran (2006), 'Public opinion as a constraint against war: democracies' responses to operation Iraqi freedom', Foreign Policy Analysis 2(2): 137-156.

Chryssogelos, A. (2018), 'Populism in foreign policy', in Thies, Cameron (eds), The Oxford Encyclopedia of Foreign Policy Analysis, Oxford, UK: Oxford University Press, pp. 427-440.

Clare, J. (2010), 'Ideological fractionalization and the international conflict behavior of parliamentary democracies', International Studies Quarterly 54(4): 965-987.

Clare, J. (2014), 'Hawks, Doves, and International Cooperation', Journal of Conflict Resolution 58(7): 1311-1337.

Clements, B. (2013), 'Public opinion and military intervention: Afghanistan, Iraq and Libya', The Political Quarterly 84(1): 119-131.

Danchev, A. and J. Macmillan (2005), The Iraq War and Democratic Politics, New York, NY: Routledge.

Devine, K. (2009), “Irish political parties” attitudes towards neutrality and the evolution of the EU's foreign, security and defence policies', Irish Political Studies 24(4): 467-490.

de Wilde, P., A. Leupold and H. Schmidtke (2016), 'Introduction: the differentiated politicisation of European governance', West European Politics 39(1): 3-22.

Ecker-Ehrhardt, M. (2014), 'Why parties politicise international institutions: on globalisation backlash and authority contestation', Review of International Political Economy 21(6): 1275-1312.

Firth, D. and A. Spirling (2003), Divisions of the United Kingdom House of Commons, from 1992 to 2003 and beyond. Retrieved 20 October 2016 from http://www.warwick.ac.uk/go/tapir/firth-spirling.pdf.

Gartner, S.S. and G.M. Segura (2008), 'All politics are still local: the Iraq War and the 2006 midterm elections', Political Science \&o Politics 41(1): 95-100.

Gemenis, K. (2013), 'What to do (and not to do) with the Comparative Manifestos Project data', Political Studies 61(1): 3-23.

Goldmann, K. (1982), 'Change and stability in foreign policy. Détente as a problem of stabilization”, World Politics 34(2): 230-266.

Gourevitch, P. (2002), 'Domestic politics and international relations', in W. Carlsnaes, T. Risse and B. Simmons (eds) Handbook of International Relations, New York: Sage Publications, pp. 309-328.

Grande, E. and H. Kriesi (2015), 'The restructuring of political conflict in Europe and the politicization of European integration', in T. Risse (ed.) European Public Spheres. Politics is Back, Cambridge, UK: Cambridge University Press, pp. 190-226.

Hermann, C.F. (1990), 'Changing course: when governments choose to redirect foreign policy', International Studies Quarterly 34(1): 3-21.

Hermann, C.F. and G. Peacock (1987), 'The evolution and future of theoretical research in the comparative study of foreign policy', in C.F. Hermann, C.W. Kegley, Jr. and J.N. Rosenau (eds), New Directions in the Study of Foreign Policy, Boston, MA: Allen \& Unwin.

Hildebrandt, T., C. Hillebrecht, P.M. Holm and J. Pevehouse (2013), 'The domestic politics of humanitarian intervention: public opinion, partisanship, and ideology', Foreign Policy Analysis 9(3): 243-266.

Hix, S., A. Noury and G. Roland (2005), 'Power to the parties: cohesion and competition in the European parliament, 1979-2001', British Journal of Political Science 35(2): 209-234. 
Hofmann, S.C. (2017), 'Party preferences and institutional transformation: revisiting France's relationship with NATO (and the common wisdom on Gaullism)', Journal of Strategic Studies 40(4): 505-531.

Hooghe, L. and G. Marks (2018), 'Cleavage theory meets Europe's crises: Lipset, Rokkan, and the transnational cleavage', Journal of European Public Policy 25(1): 109-135.

Hooghe, L., G. Marks and C.J. Wilson (2002), 'Does left/right structure party positions on European integration?', Comparative Political Studies 35(8): 965-989.

Hooghe, L., R. Bakker, A. Brigevich, C. de Vries, E. Edwards, G. Marks, J. Rovny, M. Steenbergen and M. Vachudova (2010), 'Reliability and validity of the 2002 and 2006 Chapel Hill Expert Surveys on party positioning', European Journal of Political Research 49(5): 687-703.

Huddy, L. (2013), 'From group identity to political cohesion and commitment', in L. Huddy, D.O. Sears and J.S. Levy (eds), Oxford Handbook of Political Psychology, 2nd edn, Oxford, UK: Oxford University Press, pp. 737-773.

Hutter, S., E. Grande and H.P. Kriesi (eds) (2016), Politicising Europe: Integration and Mass Politics, Cambridge, UK: Cambridge University Press.

Joly, J. and R. Dandoy (2016), 'Beyond the water's edge: how political parties influence foreign policy formulation in Belgium', Foreign Policy Analysis [online first].

Kaarbo, J. (2012), Coalition Politics and Cabinet Decision Making: A Comparative Analysis of Foreign Policy Choices, Ann Arbor, MI: University of Michigan Press.

Kaarbo, J. (2015), 'The domestic politics and decision making turn in IR theory: an FPA perspective', International Studies Review 17(2): 189-216.

Kaarbo, J. and C. Cantir (2013), 'Role conflict in recent wars: Danish and Dutch debates over Iraq and Afghanistan', Cooperation and Conflict 48(4): 465-483.

Kaarbo, J. and D. Kenealy (2016), 'Precedents, parliaments, and foreign policy: historical analogy in the house of commons vote on Syria', West European Politics 40(1): 62-79.

Keman, H. (1982), 'Security the safety of the nation-state', in F.G. Castles (ed.) The Impact of Parties, Beverly Hills, CA: Sage, pp. 177-221.

Koch, M.T. and P. Sullivan (2010), 'Should I stay or should I go: partisanship, approval and the duration of democratic military interventions', Journal of Politics 72(3): 616-629.

Kreps, S. (2010), 'Elite consensus as a determinant of alliance cohesion: why public opinion hardly matters for NATO-led operations in Afghanistan', Foreign Policy Analysis 6(3): 191-215.

Kriesi, H., E. Grande, R. Lachat, M. Dolezal, S. Bornschier and T. Frey (2008), West European Politics in the Age of Globalization, Cambridge, UK: Cambridge University Press.

Kupchan, C. and P. Trubowitz (2007), 'Dead center. The demise of liberal internationalism in the United States', International Security 32(2): 7-44.

Levine, R.A. and D.T. Campbell (1972), Ethnocentrism: Theories of Conflict, Ethnic Attitudes, and Group Behavior, New York, NY: Wiley \& Sons.

Levy, J. (1986), 'Organizational routines and the causes of war', International Studies Quarterly 30(2): $193-222$.

Lewis, V. (2017), 'The president and the parties' ideologies: party ideas about foreign policy since 1990', Presidential Studies Quarterly 47(1): 27-61.

Lichbach, M.I. and H.G.E. de Vries (2007), 'Mechanisms of globalized protest movements', in C. Boix and S.C. Stokes (eds) Handbook of Comparative Politics, Oxford, UK: Oxford University Press, pp. 461-497.

Lipset, S.M. and S. Rokkan (1967), 'Cleavage structures, party systems and voter alignments: an introduction', in S.M. Lipset and S. Rokkan (eds) Party Systems and Voter Alignments, New York, NY: Free Press, pp. 1-64.

Mello, P. (2012), 'Parliamentary peace or partisan politics? Democracies participation in the Iraq war', Journal of International Relations and Development 15(3): 420-453.

Mello, P. (2017), 'Curbing the royal prerogative to use military force. The British House of commons and the conflicts in Libya and Syria', West European Politics 40(1): 80-100.

Miyagi, Y. (2009), 'Foreign policy making under Koizumi: norms and Japan's role in the 2003 Iraq war', Foreign Policy Analysis 5(4): 349-366. 
Oktay, S. (2014), 'Constraining or enabling? The effects of government composition on international commitments', Journal of European Public Policy 21(6): 860-884.

Oneal, J.R., B. Lian and J.H. JoynerJ.H., Jr. (1996), 'Are the American people "Pretty Prudent"? Public responses to U.S. uses of force, 1950-1988', International Studies Quarterly 40(2): 261-276.

Ostermann, F. (2017), 'France's reluctant parliamentarisation of military deployments: the 2008 constitutional reform in practice', West European Politics 40(1): 101-118.

Özkeçeci-Taner, B. (2005), 'The impact of institutionalized ideas in coalition foreign policy making: Turkey as an Example, 1991-2002', Foreign Policy Analysis 1(3): 249-278.

Palmer, G., T. London and P. Regan (2004), 'What's stopping you? The sources of political constraints on international conflict behavior in parliamentary democracies', International Interactions 30(1): 1-24.

Pijovic, N. (2016), 'The Liberal National Coalition, Australian Labor Party and Africa: two decades of partisanship in Australia's foreign policy', Australian Journal of International Affairs 70(5): $541-562$.

Polk, J., J. Rovny, R. Bakker, E. Edwards, L. Hooghe, S. Jolly, J. Koedam, F. Kostelka, G. Marks, G. Schumacher, M. Steenbergen, M. Vachudova and M. Zilovic (2017), 'Explaining the salience of anti-elitism and reducing political corruption for political parties in Europe with the 2014 Chapel Hill Expert Survey data', Research \& Politics 21(1): 1-9.

Rathbun, B.C. (2004), Partisan Interventions: European Party Politics and Peace Enforcement in the Balkans, Ithaca, NY: Cornell University Press.

Rosenau, J.N. (1966), 'Pre-theories and theories and foreign policy', in R.B. Farrell (ed.) Approaches to Comparative and International Politics, Evanston, IL: Northwestern University Press, pp. 27-92.

Saalfeld, T. (1995), 'On dogs and whips: recorded votes', in H. Döring (ed.) Parliaments and Majority Rule in Western Europe, Frankfurt am Main, New York, NY: Campus/St. Martin's Press, pp. 528-565.

Schultz, K. (2001), Democracy and Coercive Diplomacy, Cambridge, UK: Cambridge University Press.

Schuster, J. and H. Maier (2006), 'The rift: explaining Europe's divergent Iraq policies in the run-up of the American-led war on Iraq', Foreign Policy Analysis 2(3): 223-244.

Simmel, G. (1955), Conflict, Glencoe, IL: Free Press.

Strong, J. (2014), 'Why parliament now decides on war: tracing the growth of the parliamentary prerogative through Syria, Libya and Iraq', British Journal of Politics and International Relations 17(4): 604-622.

Verbeek, B. and A. Zaslove (2015), 'The impact of populist radical right parties on foreign policy: the Northern League as a junior coalition partner in the Berlusconi governments', European Political Science Review 7(4): 525-546.

Volkens, A., P. Lehmann, N. Merz, S. Regel, A. Werner, O.P. Lacewell and H. Schultze (2013), The Manifesto Data Collection. Manifesto Project (MRG/CMP/MARPOR), Berlin: Wissenschaftszentrum Berlin für Sozialforschung.

Vollmer, L. (1998), Die Grünen und die Außenpolitik - ein schwieriges Verhältnis. Eine Idee-, Programmund Ereignisgeschichte grüner Außenpolitik [The Greens and foreign policy - a difficult relationship. A history of the ideas, programs and events in Green foreign policy]. Münster: Westfälisches Dampfboot.

Wagner, W., A. Herranz-Surrallés, J. Kaarbo and F. Ostermann (2017), 'The party politics of legislativeexecutive relations in security and defence policy', West European Politics 40(1): 20-41.

Waltz, K. (1967), 'Electoral punishment and foreign policy crisis', in J. Rosenau (ed.) Domestic Sources of Foreign Policy, New York, NY: Free Press, pp. 263-293.

Wheeler, N. (2000), Saving Strangers. Humanitarian Intervention in International Society, Oxford, UK: Oxford University Press.

Williams, L.K. (2014), 'Hawks, Doves, and opportunistic opposition parties', Journal of Peace Research 51(1): 111-125.

Zürn, M. (2014), 'The politicization of world politics and its effects: eight propositions', European Political Science Review 6(1): 47-71.

Zürn, M. and P. de Wilde (2016), 'Debating globalization: cosmopolitanism and communitarianism as political ideologies', Journal of Political Ideologies 2(3): 280-301.

Zürn, M. and M. Ecker-Ehrhardt (eds) (2013), Die Politisierung der Weltpolitik, Berlin: Suhrkamp. 


\section{Appendix}

Table A1. Roll-call votes in France, Germany, Spain, and the United Kingdom ${ }^{a}$

\begin{tabular}{|c|c|c|c|c|c|c|c|c|c|c|c|c|c|c|c|c|c|}
\hline \multirow[b]{3}{*}{ Country } & \multirow[b]{3}{*}{ Term $^{\mathrm{b}}$} & \multirow[b]{3}{*}{ Chamber } & \multirow[b]{3}{*}{$\begin{array}{l}\text { No. of } \\
\text { votes }\end{array}$} & \multirow[b]{3}{*}{$\begin{array}{l}\text { Share of no-votes } \\
\text { (average) }(\%)\end{array}$} & \multirow[b]{3}{*}{ AI } & \multicolumn{12}{|c|}{ Average 'no'-votes per political party family: total number and share within party family } \\
\hline & & & & & & \multicolumn{2}{|c|}{ Radical Left } & \multicolumn{2}{|c|}{ Greens } & \multicolumn{2}{|c|}{ Socialists } & \multicolumn{2}{|c|}{ Liberals } & \multicolumn{2}{|c|}{ Conservatives } & \multicolumn{2}{|c|}{ Radical Right } \\
\hline & & & & & & Total & $\begin{array}{l}\text { Share } \\
(\%)\end{array}$ & Total & $\begin{array}{l}\text { Share } \\
(\%)\end{array}$ & Total & $\begin{array}{l}\text { Share } \\
(\%)\end{array}$ & Total & $\begin{array}{l}\text { Share } \\
(\%)\end{array}$ & Total & $\begin{array}{l}\text { Share } \\
(\%)\end{array}$ & Total & $\begin{array}{l}\text { Share } \\
(\%)\end{array}$ \\
\hline France & Mitterrand ${ }^{c}$ & A & 1 & 7.6 & 0.89 & 26 & $100^{\mathrm{d}}$ & \multicolumn{2}{|c|}{$\begin{array}{c}\text { Not in } \\
\text { parliament }\end{array}$} & 7 & $2.59^{\mathrm{e}}$ & 4 & $3.1^{\mathrm{d}}$ & 4 & 3.2 & \multirow{2}{*}{\multicolumn{2}{|c|}{$\begin{array}{c}\text { Not in } \\
\text { parliament } \\
\text { Not in } \\
\text { parliament }\end{array}$}} \\
\hline France & Sarkozy & A & 2 & 21.27 & 0.66 & 15 & 66.4 & 2.5 & 75 & 88 & 48.7 & 0 & $0^{\mathrm{e}}$ & 1 & $0.3^{\mathrm{e}}$ & & \\
\hline France & Sarkozy & $S$ & 7 & 10.83 & 0.83 & 12.1 & 46.1 & 2.5 & 50 & 43.5 & 50 & 0 & $0^{\mathrm{e}}$ & 0 & $0^{\mathrm{e}}$ & \multicolumn{2}{|c|}{$\begin{array}{l}\text { Not in } \\
\text { parliament }\end{array}$} \\
\hline France & Hollande & A & 4 & 0.99 & 0.94 & 0.25 & $2.3^{\mathrm{d}}$ & 0 & $0^{\mathrm{f}}$ & 0.5 & $0.19^{\mathrm{e}}$ & 0 & 0 & 3.25 & 2.09 & 0 & 0 \\
\hline France & Hollande & S & 4 & 0.22 & 0.91 & 0 & $0^{\mathrm{d}}$ & 0 & $0^{f}$ & 0 & $0^{\mathrm{e}}$ & 0.75 & 2.42 & 0 & 0 & 0 & $0^{\mathrm{g}}$ \\
\hline Germany & Kohl IV & & 2 & 22.2 & 0.62 & 12 & 100 & 4 & 100 & 99 & 56.3 & 0.5 & $0.8^{\mathrm{e}}$ & 0 & $0^{\mathrm{e}}$ & \multicolumn{2}{|c|}{$\begin{array}{l}\text { Not in } \\
\text { parliament }\end{array}$} \\
\hline Germany & Kohl V & & 5 & 17.5 & 0.70 & 26.4 & 98.3 & 20.6 & 44.9 & 63 & 26.3 & 0.2 & $0.6^{\mathrm{e}}$ & 0.4 & $0.2^{\mathrm{e}}$ & \multicolumn{2}{|c|}{$\begin{array}{l}\text { Not in } \\
\text { parliament }\end{array}$} \\
\hline Germany & Schröder I & & 15 & 7.83 & 0.86 & 30.9 & 99 & 1.93 & $4.5^{\mathrm{e}}$ & 2.1 & $0.8^{\mathrm{e}}$ & 3.5 & 0.1 & 7.1 & 3.3 & \multicolumn{2}{|c|}{$\begin{array}{l}\text { Not in } \\
\text { parliament }\end{array}$} \\
\hline Germany & Schröder II & & 16 & 3.0 & 0.95 & 2 & 100 & 0.6 & $1.2^{\mathrm{e}}$ & 0.1 & $0^{\mathrm{e}}$ & 8.8 & 20.8 & 5.3 & 2.5 & \multicolumn{2}{|c|}{$\begin{array}{l}\text { Not in } \\
\text { parliament }\end{array}$} \\
\hline Germany & Merkel I & & 32 & 12.8 & 0.78 & 43.3 & 92.2 & 7.5 & 15.6 & 9.7 & $4.7^{\mathrm{e}}$ & 7.8 & 13.9 & 2.7 & $1.3^{\mathrm{e}}$ & \multicolumn{2}{|c|}{$\begin{array}{l}\text { Not in } \\
\text { parliament }\end{array}$} \\
\hline Germany & Merkel II & & 38 & 17.8 & 0.69 & 63.7 & 99 & 11.3 & 18 & 24.8 & 18.9 & 0.5 & $0.5^{\mathrm{e}}$ & 0.7 & $0.3^{\mathrm{e}}$ & \multicolumn{2}{|c|}{$\begin{array}{l}\text { Not in } \\
\text { parliament }\end{array}$} \\
\hline Germany & Merkel III & & 40 & 13.6 & 0.77 & 12 & 100 & 4 & 100 & 99 & 56.3 & 0.5 & $0.8^{\mathrm{e}}$ & 0 & $0^{\mathrm{e}}$ & \multicolumn{2}{|c|}{$\begin{array}{l}\text { Not in } \\
\text { parliament }\end{array}$} \\
\hline Spain & Zapatero I & & 1 & 2.06 & 0.96 & 2 & 100 & \multicolumn{2}{|c|}{$\begin{array}{c}\text { Not in } \\
\text { parliament }\end{array}$} & $1^{\mathrm{e}}$ & $0.6^{\mathrm{e}}$ & \multicolumn{2}{|c|}{$\begin{array}{l}\text { Not in } \\
\text { parliament }\end{array}$} & 1 & 0.82 & \multirow{2}{*}{\multicolumn{2}{|c|}{$\begin{array}{l}\text { Not in } \\
\text { parliament } \\
\text { Not in } \\
\text { parliament }\end{array}$}} \\
\hline Spain & Zapatero II & & 3 & 0.30 & 0.98 & 0.33 & 16.67 & $\begin{array}{r}\mathrm{N} \\
\text { parl }\end{array}$ & $\begin{array}{l}t \text { in } \\
\text { ament }\end{array}$ & $0^{\mathrm{e}}$ & $0^{\mathrm{e}}$ & $\begin{array}{r}\mathrm{N} \\
\text { par }\end{array}$ & $t$ in & 0 & 0 & & \\
\hline
\end{tabular}


Table A1. (Continued)

\begin{tabular}{|c|c|c|c|c|c|c|c|c|c|c|c|c|c|c|c|c|c|}
\hline \multirow[b]{3}{*}{ Country } & \multirow[b]{3}{*}{ Term $^{\mathrm{b}}$} & \multirow[b]{3}{*}{ Chamber } & \multirow[b]{3}{*}{$\begin{array}{l}\text { No. of } \\
\text { votes }\end{array}$} & \multirow[b]{3}{*}{$\begin{array}{l}\text { Share of no-votes } \\
\text { (average) }(\%)\end{array}$} & \multirow[b]{3}{*}{ AI } & \multicolumn{12}{|c|}{ Average 'no'-votes per political party family: total number and share within party family } \\
\hline & & & & & & \multicolumn{2}{|c|}{ Radical Left } & \multicolumn{2}{|c|}{ Greens } & \multicolumn{2}{|c|}{ Socialists } & \multicolumn{2}{|c|}{ Liberals } & \multicolumn{2}{|c|}{ Conservatives } & \multicolumn{2}{|c|}{ Radical Right } \\
\hline & & & & & & Total & $\begin{array}{l}\text { Share } \\
(\%)\end{array}$ & Total & $\begin{array}{c}\text { Share } \\
(\%)\end{array}$ & Total & $\begin{array}{c}\text { Share } \\
(\%)\end{array}$ & Total & $\begin{array}{c}\text { Share } \\
(\%)\end{array}$ & Total & $\begin{array}{l}\text { Share } \\
(\%)\end{array}$ & Total & $\begin{array}{c}\text { Share } \\
(\%)\end{array}$ \\
\hline Spain & Rajoy & & 6 & 3.06 & 0.92 & 6 & 66.67 & \multicolumn{2}{|c|}{$\begin{array}{c}\text { Not in } \\
\text { parliament }\end{array}$} & 0 & 0 & \multicolumn{2}{|c|}{$\begin{array}{c}\text { Not in } \\
\text { parliament }\end{array}$} & $0.2^{\mathrm{e}}$ & $0.10^{\mathrm{e}}$ & \multirow{3}{*}{\multicolumn{2}{|c|}{$\begin{array}{l}\text { Not in } \\
\text { parliament } \\
\text { Not in } \\
\text { parliament } \\
\text { Not in } \\
\text { parliament }\end{array}$}} \\
\hline $\begin{array}{l}\text { United } \\
\text { Kingdom }\end{array}$ & Blair & & 1 & 26.56 & 0.6 & \multirow{3}{*}{\multicolumn{2}{|c|}{$\begin{array}{l}\text { Not in } \\
\text { parliament } \\
\text { Not in } \\
\text { parliament } \\
\text { Not in } \\
\text { parliament }\end{array}$}} & \multicolumn{2}{|c|}{$\begin{array}{l}\text { Not in } \\
\text { parliament }\end{array}$} & 84 & $24.85^{\mathrm{e}}$ & 52 & 100 & 2 & 1.35 & & \\
\hline $\begin{array}{l}\text { United } \\
\text { Kingdom }\end{array}$ & \multicolumn{2}{|l|}{ Cameron I } & 4 & 16.34 & 0.76 & & & 1 & 100 & 65.75 & 35.05 & 3.25 & $8.53^{\mathrm{e}}$ & 9.5 & $3.49^{\mathrm{e}}$ & & \\
\hline $\begin{array}{l}\text { United } \\
\text { Kingdom }\end{array}$ & \multicolumn{2}{|l|}{ Cameron II } & 1 & 35.97 & 0.46 & & & 1 & 100 & 153 & 69.86 & 2 & 25 & 7 & $2.17^{\mathrm{e}}$ & 0 & 0 \\
\hline
\end{tabular}

$\mathrm{AI}=$ Agreement Index.

${ }^{a}$ In this and in subsequent tables, the average share of no-votes is calculated by dividing the number of no-votes by the total number of votes from members of a particular political party. The total number of no-votes represents an average of no-votes over the whole legislature, calculated by dividing the number of no-votes by the number of overall separate votes on missions per legislature.

${ }^{b}$ Because of the different electoral cycles of the two French chambers, this table takes the presidencies of Mitterrand, Sarkozy and Hollande as a structuring device.

${ }^{c}$ For lack of more precise data, we counted the full group votes here.

${ }^{\mathrm{d}}$ Partially in government.

e In government.

${ }^{\mathrm{f}}$ Temporally in government

${ }^{g}$ The FN has only two senators from the 2014 election round onwards. Thus, they only voted on the two anti-Daesh missions in Iraq and Syria. 
